\title{
RUSSIAN WORD-FORMATION IN CONTRAST WITH CZECH AND NORWEGIAN
}

\author{
LAURA A. JANDA \\ University of Tromsø
}

\section{ABSTRACT}

Although some scholarship on metonymy has mentioned examples of wordformation and some scholarship on word-formation has mentioned the presence of metonymy, to date there has been no attempt to examine the systematic role of metonymy in the domain of word-formation. This article presents an empirical study of the metonymies signalled by derivational suffixes in Russian, Czech and Norwegian. This approach facilitates crosslinguistic comparison that reveals significant differences among languages, and these differences appear relevant to cultural differences.

\section{[1] INTRODUCTION}

Examples (1) and (2) illustrate lexical metonymy with parallels to word-formation in Russian and Czech.

(1) PART FOR WHOLE

a. We need a good head for this project.

b. (Russian) brjuxan (lit. 'belly'-an) 'person with a large belly'

c. (Czech) břicháč (lit. 'belly'-áč) 'person with a large belly'

(2) CONTAINED FOR CONTAINER

a. The milk tipped over. (cf. Peirsman \& Geeraerts 2006: 281)

b. (Russian) saxarnica (lit. 'sugar'-nica) 'sugar-bowl'1

c. (Czech) květináč (lit. 'flower'-áč) 'flower-pot'

In keeping with current scholarly convention, the metonymy designations in (1) and (2) are identified in terms of VEHICLE FOR TARGET (Kövecses \& Radden 1998; Radden \& Kövecses 1999; Panther \& Thornburg 1999, 2007; Peirsman \& Geeraerts 2006). In (1) a body PART (head or belly) serves as the VEHICLE through which the speaker refers to the TARGET, which is a WHOLE person. Although the speaker in (1-a) is primarily interested in the brains of the future employee, they must hire

[1] In this article I do not attempt to distinguish between suffix and desinence (as in Russian -nica, which could be segmented as -nic-a) because issues of morphophonemics make this segmentation difficult and/or artificial in some cases, and for the purposes of this article, such segmentation is not necessary. 
an entire person, and this is a classic example of lexical metonymy. In (1-b) and (1-c) we see the same PART FOR WHOLE metonymy at work, this time signalled by the presence of a suffix. Metonymy is not limited to PART FOR WHOLE relationships; it covers a range of other types of contiguity, including CONTAINED FOR CONTAINER as illustrated in (2). In (2-a) it is not the milk itself that has tipped over, but the glass or carton that the milk is (or was) in. Both Russian and Czech invoke this metonymy when they derive the names for CONTAINERS from nouns that refer to what is CONTAINED in them in (2-b) and (2-c).

Several important observations can be made even on the basis of this modest set of examples. Firstly, there are clear parallels between the use of metonymy in lexicon and in word-formation. Secondly, the presence of a suffix does not in and of itself determine the metonymy designation: we see that Czech -áč can be used for both PART FOR WHOLE and CONTAINED FOR CONTAINER. This same suffix can signal a third metonymy designation, namely CHARACTERISTIC FOR ENTITY, as we see in the word nahác 'naked person', derived from the adjective nahý 'naked'. The Russian suffix in (2-b), -nica, can likewise signal a second metonymy: ACTION FOR LOCATION, as in varnica 'saltworks' derived from the verb varit' 'cook'. Some suffixes are even more versatile, with the maximum number of metonymy designations per suffix at sixteen for Czech, fifteen for Russian, and eleven for Norwegian. A third observation is that the extent of metonymic word-formation is different in different languages: whereas both PART FOR WHOLE and CONTAINED FOR CONTAINER are robustly represented in Russian (nine and three suffixes respectively) and Czech (nine and eleven suffixes respectively), neither of these metonymy designations are attested for Norwegian, which has overall a more restricted system of affixal word-formation. This third observation demonstrates that word-formation systems provide a basis for discovering significant differences among languages. Discovering such differences is the main objective of this article.

\section{[1.1] Relevant previous scholarship}

The scholarly literature relevant to this article can be divided into roughly two groups: there are works on metonymy that make only scattered mention of wordformation, and there are works on word-formation that rarely make reference to metonymy. This subsection provides a brief overview, focusing on the works that indicate a connection between word-formation and metonymy.

Langacker $(2009,1993)$ describes metonymy as a pervasive phenomenon, not only in language, but in cognition in general. If this is the case, then we should expect metonymy to play a role across the entire spectrum of the grammar-tolexicon continuum. However, the majority of linguistic scholarship on metonymy has focused nearly exclusively on the lexicon. Peirsman \& Geeraerts (2006) pro- 
vide a state-of-the-art inventory of scholarly works on metonymy, but their compilation is nearly exclusively focused on lexical use of metonymy. ${ }^{2}$

Padučeva $(2004,147,163)$, in a discussion of lexical metonymy, mentions that a metonymy expressed lexically in one language might be expressed via wordformation in another and gives two examples. Though Koch (1999) specifically argues that metonymy plays a major role in word-formation, he offers only a pair of examples from the history of French. Several works analyze metonymy in a single affix or a small group of affixes: Basilio (2006) in connection with three suffixes in Brazilian Portuguese, Panther \& Thornburg (2002) in connection with English -er, and Radden (2005) in connection with English -able. The remaining works on metonymy in word-formation focus on the marginal phenomena of conversion (also known as "zero derivation"; cf. Warren 1999 and Dirven 1999) and compounding (Benczes 2005; Langacker 2009), and all these works examine English.

Traditional works on word-formation are basically lists of affixes (cf. reference grammars such as Švedova 1980; Dokulil 1986; Faarlund et al. 1997). They make no mention of metonymy and the semantic analyses they offer are ad hoc and idiosyncratic, hindering cross-linguistic comparisons. Most other works on word-formation of Russian and Czech follow this pattern, though occasionally with more insight (Šanskij 1968; Townsend 1975; Janda \& Townsend 2000; Townsend \& Komar 2000; McFadden 1975; Maksimov 1975; Andrews 1996). Theoretical works on word-formation are generally quite abstract (cf. Dokulil 1962; Mel'čuk 1996 and usually offer only a modest set of examples, rather than carrying out the analysis across the system of an entire language. Araeva $(2009,25)$, in a catalog of hundreds of examples of word-formation from the Kemer dialect of Russian, acknowledges that metonymy plays a role in just three examples. All three of her examples illustrate PART FOR WHOLE/WHOLE FOR PART: medvežatina 'bearmeat' derivd from medved' 'bear'; gorošina 'pea' derived from gorox 'peas (collective)'; and zver'e 'beasts (collective)' derived from zver' 'beast'.

In sum, existing scholarship on metonymy provides little in the way of analysis of word-formation, and the few works that do exist analyze either a single or a handful of affixes, or focus instead on conversion or compounding. These few works are primarily based on English, a language where massive borrowing has compromised the word-formation system. Traditional presentations of wordformation are inventories of affixes, with virtually no mention of metonymy. A systematic study of the role of metonymy in word-formation is lacking.

[2] Peirsman \& Geeraerts' (2006) inventory includes one use of metonymy sometimes identified as "grammatical", namely the POTENTIAL FOR ACTUAL metonymy observed in the use of can in a phrase like Can you open the window?, where the speaker is not interested in the hearer's ability to open windows, but is using this form in place of an imperative. This type of example is perhaps best interpreted as a pragmatic use of a lexical item rather than a grammatical one. At any rate, this use is not as systematic and widespread as the grammatical function of word-formation. 


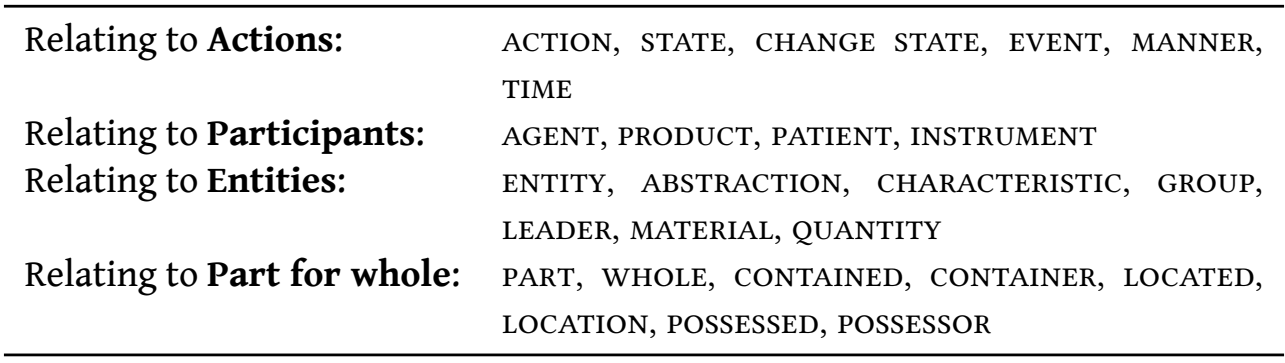

TABLE 1: Classificatory terms for VeHICLES and TARGETS

\section{[1.2] Data and methodology}

The goals of the present study have dictated the design of the classification system. There are two goals: 1) to explore the extent of metonymy in word-formation, and 2) to facilitate cross-linguistic comparisons. To this end, it was prudent to devise a classification that would 1) reflect the range of semantic relationships that can be considered metonymic, and 2) be applicable across various languages. Since there is no such previously existing classification for metonymy in wordformation, I chose the best available model: Peirsman \& Geeraerts' (2006: henceforth $P \& G$ ) inventory of metonymy in the lexicon. It was necessary to slightly modify the $P \& G$ inventory because it turns out that metonymy is somewhat more diverse in word-formation than in the lexicon.

The $P \& G$ inventory of lexical metonymy consists of a series of terms that can serve either as the VEHICLE or as the TARGET in a metonymic relationship. Table 1 presents the terms used in my modified classification for metonymy in wordformation. The terms are organized according to thematic groups. The only term in Table 1 that has no equivalent in the P\&G inventory is QUANTITY, which was essential due to the presence of words derived from numerals in all three languages. Otherwise all adjustments that have been made are along the scale of specific to abstract: PARTICIPANT, for example, has been broken down into several more specific terms, and ABSTRACTION has been added as a more abstract version of ENTITY.

A database of TYPEs was collected for each of the three languages. A type is a unique combination of three items: 1 ) a metonymy designation (giving the terms for the VEHICLE and TARGET), 2) a word class designation (giving the word class of both the VEHICLE word and the TARGET word), and 3) an affix. Each type was additionally supplied with an illustrative example. Table 2 on the next page lists some sample entries from the databases.

In order to keep the project manageable and the data comparable across languages, several limitations were imposed. Further restrictions were necessary 


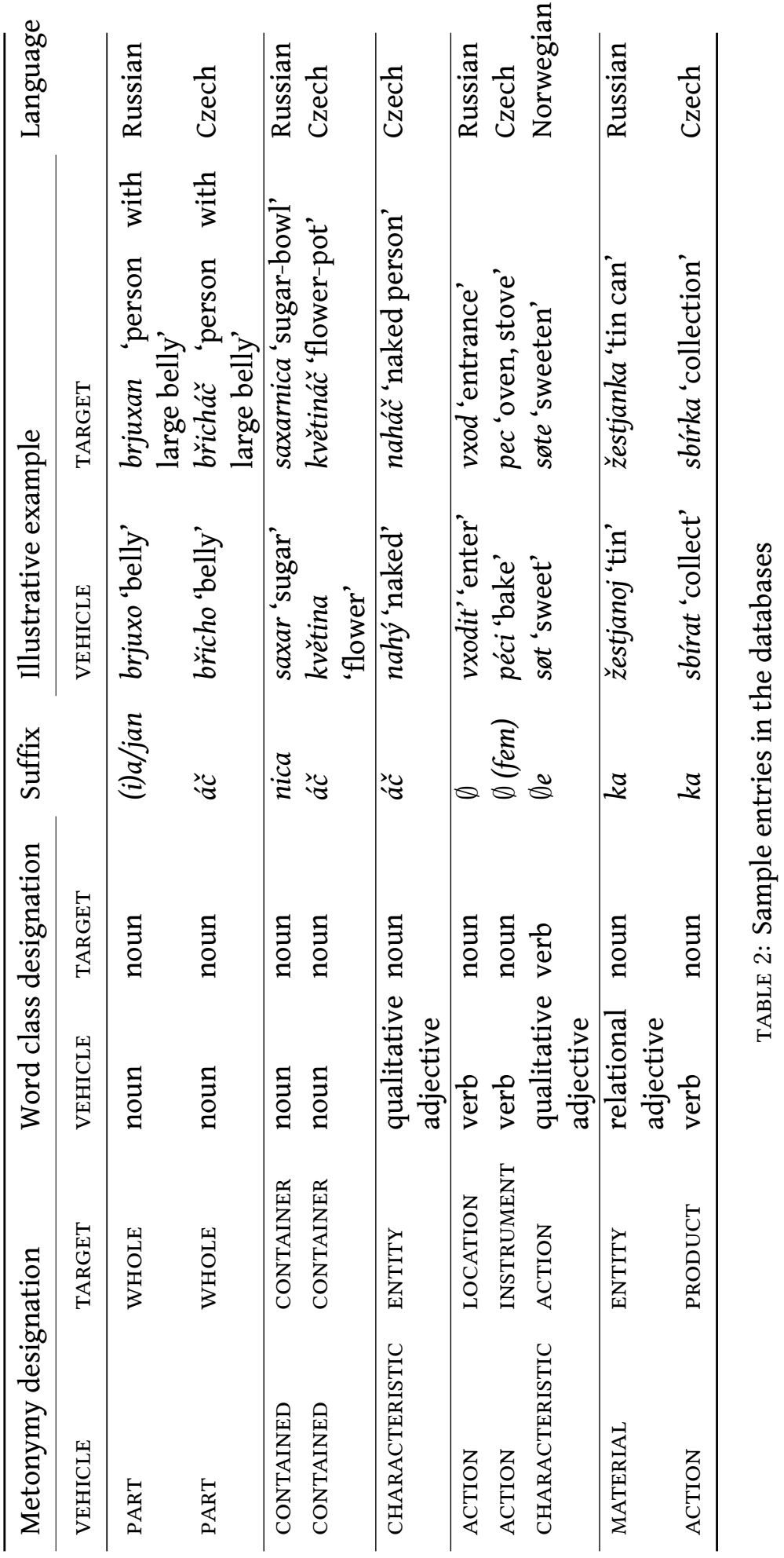


to remove from consideration data that does not represent metonymic relationships.

This project is limited to suffixal word-formation. This limitation is motivated by two factors: 1) while all three languages also use prefixes to derive words, the majority of word-formation is accomplished via suffixation, 2) the primary purpose of prefixal word-formation in the Slavic languages is for signalling aspect, which is not represented in a commensurate way in a Germanic language such as Norwegian. In regard to the second factor, aspectual suffixes, such as the semelfactive -nu/-nou and suffixes used to derive imperfectives were also eliminated from this study. This was done in order to level the playing field so that the databases would represent comparable subsystems across the three languages. This does not, however, mean that metonymy is irrelevant to aspect (cf. Janda 2008; Nesset 2009), just that it was not included in this study.

Although the study reveals that the majority of word-formation is motivated by metonymic relationships, some types of word-formation do not involve metonymy and were thus eliminated from consideration. This includes the formation of hypocoristics (such as Russian knižka 'book (dim.)' derived from kniga 'book'), formations that merely change the gender (as in Czech učitelka 'female teacher' derived from učitel 'teacher'), and the formation of deverbal nouns when they lack any specialized meaning (as in Norwegian maling in the meaning 'action of painting' from male 'paint'; note, however, that maling in the meaning 'paint' is metonymic, signalling ACTION FOR MATERIAL).

Any morphological system presents issues of allomorphy, where it is necessary to decide whether a group of items are merely variants of each other or separate units. On issues of allomorphy, I followed the lead of the three reference grammars (Švedova 1980; Dokulil 1986; Faarlund et al. 1997), which are in fairly good agreement. When variants are predictable according to the morphophonemics of the language, they are considered to be allomorphs and thus not separate units. This includes automatic variations due to prosody and phonotactics. Thus, for example, Russian is acknowledged as having only one suffix that could be realized as -nyj (as in mesjačnyj 'monthly' derived from mesjac 'month' via TIME FOR CHARACTERISTIC) or -noj (as in oblastnoj 'regional' derived from oblast' 'region' via LOCATION FOR CHARACTERISTIC) depending on stress. On the other hand, nonautomatic variants are treated as separate units, even when an etymological relationship is obvious. Thus Russian -nica (as in saxarnica 'sugar-bowl') is recognized as distinct from the related -ica (as in teplica 'hot-house' derived from teplyj 'hot' via CHARACTERISTIC FOR LOCATION). Furthermore, all three reference grammars recognize conversion as a type of zero-suffixation (cf. Russian vxod 'entrance' derived from vxodit' 'enter' via ACTION FOR LOCATION, Czech pec 'oven, stove' derived from péci 'bake' via ACTION FOR INSTRUMENT, and Norwegian søte 'sweeten' derived from søt 'sweet' via CHARACTERISTIC FOR ACTION). I do not take a stand on whether 


\begin{tabular}{lllll}
\hline Language & \# types & $\begin{array}{l}\text { \# metonymy } \\
\text { designations }\end{array}$ & $\begin{array}{l}\text { \# word class } \\
\text { designations }\end{array}$ & \# suffixes \\
\hline Russian & 747 & 110 & 33 & 274 \\
Czech & 561 & 105 & 23 & 207 \\
Norwegian & 177 & 60 & 12 & 57 \\
\hline
\end{tabular}

TABLE 3: Total size of databases in terms of types, metonymy designations, word class designations, and suffixes

zero-morphemes exist, since that issue goes beyond the scope of this study, but I do include examples of conversion in the databases.

Dialectal and colloquial forms are not considered in this study, which also excludes forms that are restricted to a highly marked register (jargon, slang, etc.). Since the aim is to explore systematic types of word-formation, isolated examples are also excluded.

Finally, no kind of frequency information is included in the databases. Each entry consists of a unique type in terms of metonymy designation, word class designation and suffix, and no types are repeated, nor do the databases include any information on type or token frequency. Some types might represent only a couple of derived words, whereas others may represent hundreds of words. And some of the derived words might be relatively rare, whereas others are of high frequency. All of this information is certainly important, but was excluded in this preliminary study, since the goal was to map out the extent of metonymy in word-formation. Frequency can be taken up in future studies.

Table 3 presents the overall dimensions of the databases, which are based primarily on the three reference grammars. These figures cannot be considered absolute metrics given that we are dealing with dynamic open-ended systems and the three grammars may differ in how exhaustive their inventories are. However, the relative sizes are probably indicative of real differences in the three languages. By all measures, the two Slavic languages have much more extensive word-formation systems than Norwegian, but Czech (historically strongly influenced by German) has a somewhat less extensive system than Russian. Over three times as many types are recognized for Czech word-formation than for Norwegian, and Russian yields over four times as many types. This difference is indicative of a different overall strategy between Slavic vs. Germanic languages, where much of the "work" done by word-formation is taken care of by compounding instead (cf. Nesset 2010). In terms of metonymy designations, Russian and Czech are nearly equivalent, and those numbers are nearly double what we find in Norwegian. Overall, the metonymy designations found in word-formation are considerably more diverse than those found in the lexicon. Taken together, there 
are 133 different metonymy designations attested across the word-formation systems of the three languages. When we compare these metonymy designations with those found in the lexicon (inventoried in $P \& G$ ), we find nine designations that are attested only in the lexicon, seventy-nine that are shared by lexicon and word-formation, and fifty-four that are found only in word-formation (for more discussion of this distribution and examples, see Janda forthcoming). Though the phenomenon of metonymy is uniform enough to be classified by the same system across both lexicon and word-formation, it is more diverse in the latter and this increased diversity is largely due to greater combinability of terms.

\section{[2] ANALYSIS}

The data in this study can be examined from various different angles, but the purpose of this article is to highlight contrasts. On a number of parameters, the three languages behave very similarly. The purpose of this section is to sort through some of the possible parameters and identify those that yield the most meaningful contrasts.

It is possible, for example, to look at the relationship of metonymy designations to suffixes and the relationship of word class designations to suffixes. It is also possible to probe the metonymy designations in more detail, looking at the relative numbers of VEHICLES vs. TARGETS signalled by a given suffix. Yet another opportunity for comparison is presented by the distribution of bi-directional vs. unidirectional metonymy relationships. In a bi-directional metonymy relationship the same terms can serve as both VEHICLE and TARGET; for example, ACTION FOR AGENT (cf. Russian tancovščik 'dancer' derived from tancevat' 'dance') and AGENT FOR ACTION (cf. Russian šoferit' 'work as a driver' derived from šofer 'driver') constitute a bi-directional metonymy relationship. By contrast, PRODUCT FOR AGENT (cf. Russian lampovščik 'lamp-maker' derived from lampa 'lamp') is a unidirectional metonymy relationship since AGENT FOR PRODUCT is not attested for Russian wordformation. Tautological metonymy relationships such as CHARACTERISTIC FOR CHARACTERISTIC (cf. Russian veličavyj 'majestic' derived from velikij 'great') constitute a special type of bi-directional relationship.

However, the above-named parameters yield very similar results across the three languages, as summarized in Table 4 on the next page.

The average numbers of metonymy and word class designations per suffix show us that suffixes are not very specific in terms of the metonymies they signal, but they are quite specific as to the word classes they designate. Indeed, the majority of variation associated with word class designations involves the word class of the VEHICLE, not the TARGET. Taken together, these two metrics suggest that we can paraphrase the role of the suffix as follows: take the VEHICLE word and derive a word of word class " $X$ ", but the metonymy relation is not usually specified by the suffix. The data in Table 5 on page 252 illustrate this difference in the 


\begin{tabular}{lllll}
\hline Language & $\begin{array}{l}\text { Average } \\
\text { metonymy } \\
\text { designations } \\
\text { per suffix }\end{array}$ & $\begin{array}{l}\text { Average word } \\
\text { class designa- } \\
\text { tions per suf- } \\
\text { fix }\end{array}$ & $\begin{array}{l}\text { Percent of } \\
\text { suffixes } \\
\text { where \# of } \\
\text { TARGETs } \\
\text { exceeds \# of } \\
\text { vEHICLES }\end{array}$ & $\begin{array}{l}\text { Percent of } \\
\text { bi-directional } \\
\text { metonymy } \\
\text { relationships }\end{array}$ \\
\hline Russian & 2.6 & 1.55 & $11.0 \%$ & $43 \%$ \\
Czech & 2.6 & 1.55 & $12.5 \%$ & $47 \%$ \\
Norwegian & 3.0 & 1.63 & $17.5 \%$ & $45 \%$ \\
\hline
\end{tabular}

TABLE 4: Specificity of suffixes and metonymy designations

specificity of metonymy and word class designations in relation to the Russian suffix -ina.

Russian -ina can form nouns from adjectives, verbs, and nouns, but the TARGET is always a noun. This suffix is highly non-specific in terms of the metonymy designations it can signal. There are fifteen metonymy designations, with eight different TARGETS. Thus, while Russian -ina tells us to form a noun from the VEHICLE word, it does not give us much more information than that. Similar examples are common for both Czech and Norwegian.

The third parameter in Table 4 involves the balance of VEHICLES to TARGETS in metonymy designations. If, as in the case of word class designations, the diversity of metonymy designations were largely a matter of various VEHICLES with a single TARGET, then there would be high determinacy in the system. However, this is not the case. Whereas $60 \%$ of suffixes do have a single TARGET, $40 \%$ have multiple TARGETS, and from $11 \%$ to $17.5 \%$ have more TARGETS than VEHICLES. Russian -ina shows how non-specific a suffix can be even when the number of TARGETs does not exceed the number of VEHICLES, since -ina has eight VEHICLES and eight TARGETS.

The last measure listed in Table 4 involves the balance of bi-directional vs. unidirectional metonymy designations. Once again, the data in Table 5 on the following page can illustrate this phenomenon. We see that the same suffix can even mark both directions of a bi-directional metonymy relation. Russian -ina is used to signal both MATERIAL FOR ENTITY in the formation of l'dina 'ice-floe' and ENTITY FOR MATERIAL in the formation of konina 'horse-meat'. Though it is unusual for a single suffix to signal the opposing directions of a metonymy relationship in this way, it is clearly not impossible, and this is another demonstration of how non-specific suffixes can be in terms of the metonymies they can signal.

However, all of the parameters listed in Table 4 yield very similar dimensions for the three languages. These parameters are valuable for establishing crosslinguistic generalizations, for discovering regularities in how metonymy func- 


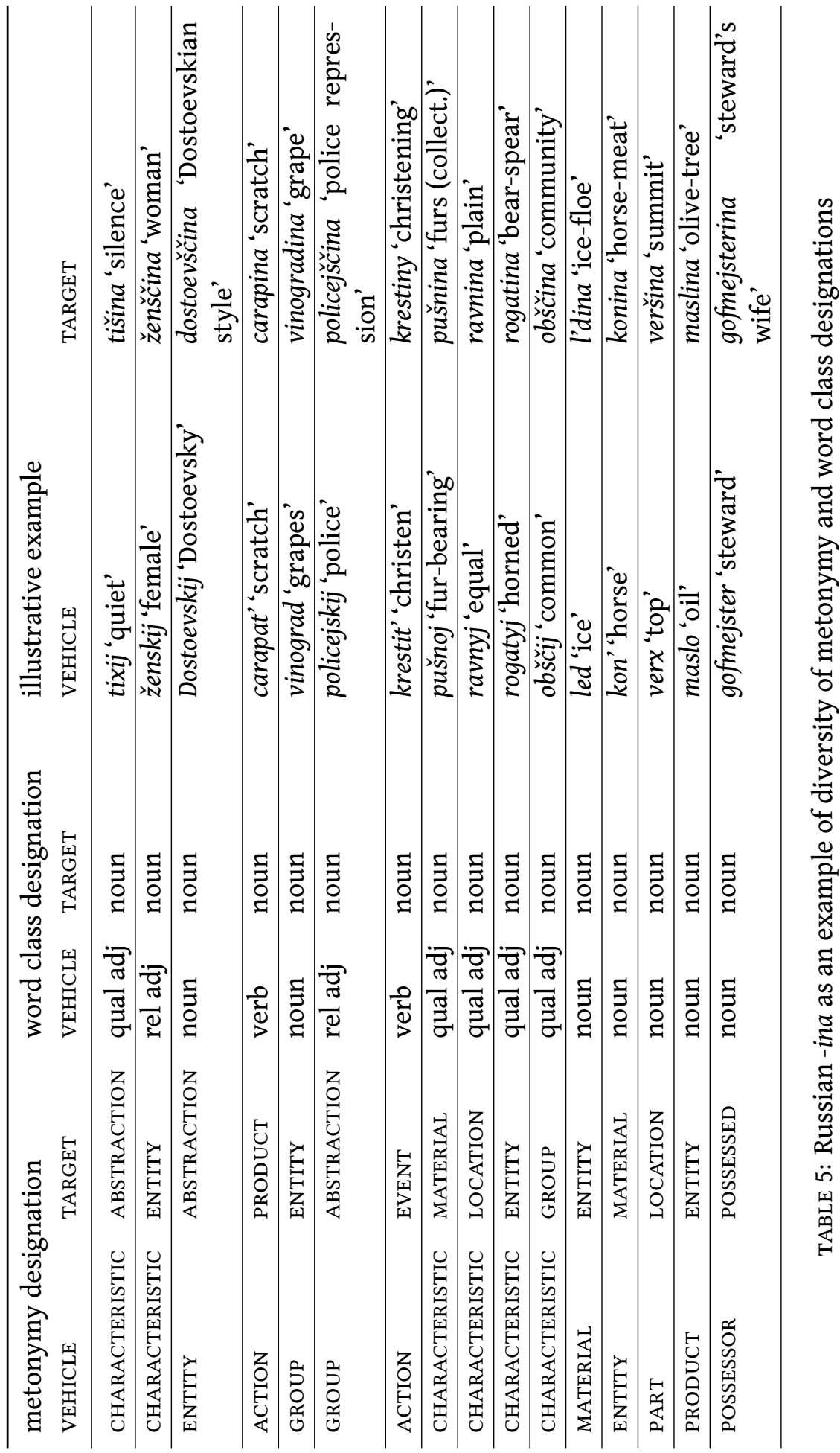




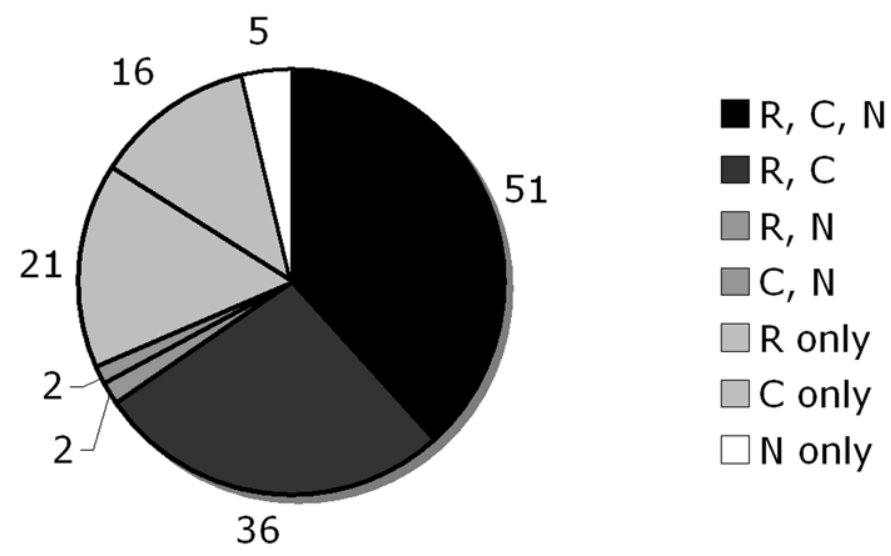

FIGURE 1: Distribution of metonymy designations across the three languages

tions in word-formation. But these parameters do not reveal differences between languages. In order to probe such differences it is necessary to find differences in which metonymies occur in which languages. In the remainder of this section we focus on the following questions: Are there metonymies that occur only in one or two of the three languages? Are there metonymies that are more strongly represented in one or two of the three languages?

Summing across the three languages, a total of 133 metonymy designations are attested in the databases. Figure 1 illustrates the distribution of these metonymies across Russian, Czech, and Norwegian. While fifty-one designations are shared by all three languages, eighty-two are found in only one or two languages. Nearly half of the latter are shared by two languages, with the bulk of these, thirty-six metonymies, attested in Russian and Czech, but absent in Norwegian. The remaining forty-two metonymies are unique to a single language in this group. However, the metonymies that are strongly represented in the languages - represented by several suffixes - still tend to be the same ones. If we look at the metonymies signaled by the most suffixes in each language, the same ten items are among the top fourteen for all three languages. These top ten metonymy designations are listed in Table 6 on the next page.

We can look beyond these similarities to find the metonymies that are proportionally more prominent in one or two languages than in the remainder. Table 7 on page 255 presents such prominent suffixes identified for the two Slavic languages as opposed to Norwegian and for each of the individual languages.

Table 7 begins with a group of metonymy designations that are common in both Russian and Czech, but rare or absent in Norwegian. LOCATION FOR CHAR- 


\begin{tabular}{|c|c|c|c|}
\hline \multirow[t]{2}{*}{ Metonymy designation } & \multicolumn{2}{|c|}{ Illustrative example } & \multirow[t]{2}{*}{ Language } \\
\hline & Vehicle & Target & \\
\hline ABSTRACTION FOR CHARACTERISTIC & $\begin{array}{l}\text { mysl' } \\
\text { 'thought' }\end{array}$ & $\begin{array}{l}\text { myslennyj } \\
\text { 'mental' }\end{array}$ & Russian \\
\hline ACTION FOR ABSTRACTION & myslit 'think' & $\begin{array}{l}\text { myšlenka } \\
\text { 'idea' }\end{array}$ & Czech \\
\hline ACTION FOR AGENT & bake 'bake' & baker 'baker' & Norwegian \\
\hline ACTION FOR CHARACTERISTIC & bereč' 'guard' & $\begin{array}{l}\text { berežnyj } \\
\text { 'careful' }\end{array}$ & Russian \\
\hline ACTION FOR INSTRUMENT & sušit 'dry' & $\begin{array}{l}\text { sušička } \\
\text { 'dryer' }\end{array}$ & Czech \\
\hline ACTION FOR PRODUCT & $\begin{array}{l}\text { stifte 'estab- } \\
\text { lish' }\end{array}$ & $\begin{array}{l}\text { stiftelse 'es- } \\
\text { tablishment' }\end{array}$ & Norwegian \\
\hline CHARACTERISTIC FOR ABSTRACTION & tixij 'quiet' & $\begin{array}{l}\text { tišina } \\
\text { lence' }\end{array}$ & Russian \\
\hline ENTITY FOR CHARACTERISTIC & Kafka & $\begin{array}{l}\text { kafkovský } \\
\text { 'Kafkaesque' }\end{array}$ & Czech \\
\hline CHARACTERISTIC FOR ENTITY & tøff 'tough' & $\begin{array}{l}\text { tøffing 'tough } \\
\text { guy' }\end{array}$ & Norwegian \\
\hline ACTION FOR EVENT & $\begin{array}{l}\text { zabastovat' } \\
\text { 'go on strike' }\end{array}$ & $\begin{array}{l}\text { zabastovka } \\
\text { 'strike' }\end{array}$ & Russian \\
\hline
\end{tabular}

TABLE 6: Top ten metonymy designations shared by all three languages

ACTERISTIC is signaled by twenty-two suffixes in Russian and by fourteen suffixes in Czech, but only two suffixes are associated with that metonymy designation in Norwegian. POSSESSOR FOR POSSESSED, signaled by eighteen Russian suffixes and eleven Czech suffixes, is signaled by only one suffix in Norwegian. The remaining metonymy designations in that group are unattested in Norwegian.

The Russian section of Table 7 lists three metonymy designations that are particularly strong in that language. CHARACTERISTIC FOR MATERIAL is associated with nine Russian suffixes, but with only three Czech suffixes and no Norwegian suffixes. The other two designations in this section of Table 7 are exclusive to Russian. These designations suggest that Russian is particularly strong in metonymies that involve CHARACTERISTICS.

Czech excels in deriving nouns via three metonymy relationships that are either unattested or rare in the other two languages. PRODUCT FOR LOCATION is not found in Russian or Norwegian, and CONTAINED FOR CONTAINER is not found in Norwegian; otherwise these three relationships are represented by three or fewer suffixes in the other languages. 


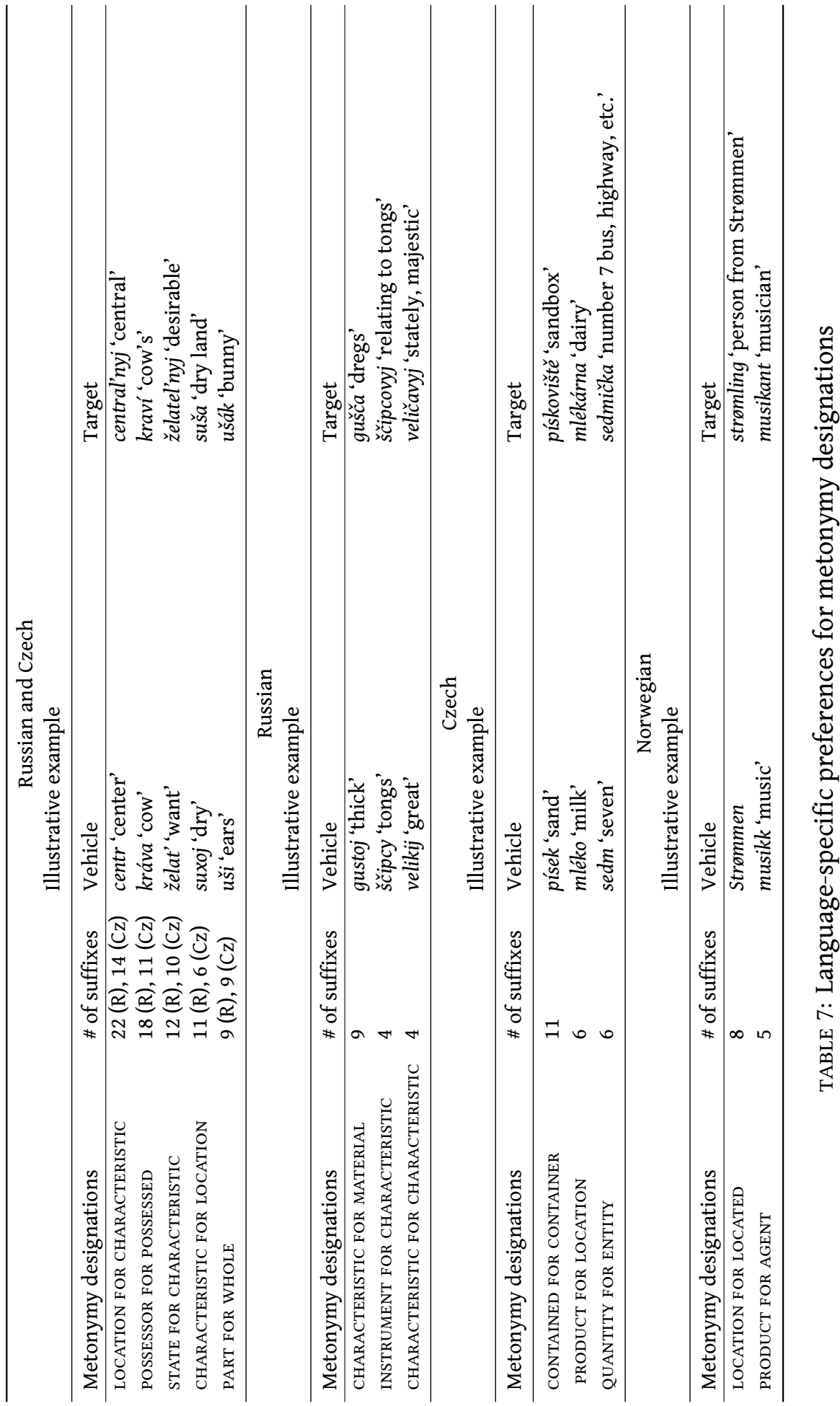


The two metonymy designations that are flagged for Norwegian are attested robustly in both Russian and Czech, but are ranked relatively higher (eighth and eleventh most common) in Norwegian. LOCATION FOR LOCATED, though it can identify objects in addition to people in both Russian and Czech, is specialized only to human targets in Norwegian.

It is tempting to speculate on possible cultural parallels to language-specific patterns. In addition to the bias toward CHARACTERISTICs noted above for Russian, Czech appears to be very focused on quantification and commercial transactions. Norwegian preference for LOCATION FOR LOCATED seems to correspond to a strong sense of the connection between location and personal identity in Norway. Future studies could show whether there are indeed cultural parallels to metonymy preferences among languages.

\section{[3] CONCLUSIONS}

This article opens up a new parameter for comparing languages, by means of comparing their word-formation systems. Word-formation systems tend to be unwieldy and to appear intractable for cross-linguistic comparison. However, when word-formation is understood in terms of metonymy designations the comparisons can become both feasible and meaningful. This article reports on a pilot study of three languages, Russian, Czech, and Norwegian, using a classification system based on the inventory of lexical metonymic relations known to linguistic scholarship. Surprisingly, we discover that the diversity of metonymy that underlies word-formation is even more extensive than the semantic shifts that motivate lexical metonymy. Some tendencies turn out to be fairly uniform across the three languages, such as the ratio of word classes to suffixes, the degree of metonymic target specificity for suffixes, and the balance of bi-directional vs. unidirectional metonymy relations. There is a top ten list of metonymies that are equally robust in all three languages, but further comparison reveals that some metonymies are proportionally stronger in some languages than in others. Thus despite the many similarities, there are also differences in what metonymic relations different languages invest in. More research needs to be done on the word-formational systems of a greater variety of languages in order to verify and fine-tune the classification system. This line of inquiry has the potential to reveal patterns of semantic association that may have important cultural parallels as well.

\section{ACKNOWLEDGEMENTS}

This research has been supported by grants from Norges forskningsråd and Sparebank1. 


\section{REFERENCES}

Andrews, Edna. 1996. The semantics of suffixation: agentive substantival suffixes in Modern Standard Russian (LINCOM Studies in Slavic Linguistis 5). Munich: LINCOM Europa.

Araeva, L. A. 2009. Slovoobrazovatel'nyj tip. Moscow.

Basilio, Margarida. 2006. Metaphor and metonymy in word-formation. DELTA: Revista de Documentação de Estudos em Lingüïstica Teórica e Aplicada 22. 67-80.

Benczes, Réka. 2005. Creative noun-noun compounds. Annual Review of Cognitive Linguistics 3. 250-268.

Dirven, René. 1999. Conversion as a conceptual metonymt of event schemata. In Klaus-Uwe Panther \& Günter Radden (eds.), Metonymy in language and thought (Human Cognitive Processing 4), 275-287. Amsterdam: John Benjamins.

Dokulil, Miloš. 1962. Tvoření slov v češtině. 1: Teorie odvozování slov. Praha: ČSAV.

Dokulil, Miloš. 1986. Mluvnice češtiny (1). Praha: Academia.

Faarlund, Jan Terje, Svein Lie \& Kjell Ivar Vannebo. 1997. Norsk referansegrammatikk. Oslo: Universitetsforlaget.

Janda, Laura A. 2008. Metonymy via perfectivization of Russian verbs. In S ljubov'ju $k$ slovu. Festschrift in honour of Professor Arto Mustajoki on the occasion of his 60th birthday (Slavica Helsingiensia 35), 77-85.

Janda, Laura A. forthcoming. Metonymy in word-formation. Forthcoming MS.

Janda, Laura A. \& Charles E. Townsend. 2000. Czech (Languages of the World/Materials 125). Munich, Newcastle: LINCOM Europa.

Koch, Peter. 1999. On the cognitive bases of metonymy and certain types of word formation. In Klaus-Uwe Panther \& Günter Radden (eds.), Metonymy in language and thought (Human Cognitive Processing 4), 139-167. Amsterdam: John Benjamins.

Kövecses, Zoltán \& Günter Radden. 1998. Metonymy: developing a cognitive linguistic view. Cognitive Linguistics 9. 37-77.

Langacker, Ronald W. 1993. Reference-point constructions. Cognitive Linguistics 4 . 1-38.

Langacker, Ronald W. 2009. Metonymic grammar. In Klaus-Uwe Panther, Linda L. Thornburg \& Antonio Barcelona (eds.), Metonymy and metaphor in grammar (Human Cognitive Processing 25), 45-71. Amsterdam: John Benjamins. 
Maksimov, V. I. 1975. Suffiksal'noe slovoobrazovanie imen suščestvitel'nyx v russkom jazyke. Leningrad: Izdatel'stvo LGU.

McFadden, Kenneth Dallas. 1975. The morphophonemics of adjectival derivation in Russian: University of Michigan dissertation.

Mel'čuk, I. A. 1996. Lexical functions: a tool for the description of lexical relations in a lexicon. In Leo Wanner (ed.), Lexical functions in lexicography and natural language processing (Studies in Language Companion Series 31), 37-102. Amsterdam: John Benjamins.

Nesset, Tore. 2009. Metonymy of aspect/aspects of metonymy. Scando-Slavica 55. 65-77.

Nesset, Tore. 2010. The art of being negative: metonymical morphological constructions in contrast. This volume.

Padučeva, E. V. 2004. Dinamičeskie modeli v semantike leksiki. Moscow: Jazyki slavjanskoj kul'tury.

Panther, Klaus-Uwe \& Linda L. Thornburg. 1999. The potentiality for actuality metonymy in English and Hungarian. In Klaus-Uwe Panther \& Günter Radden (eds.), Metonymy in language and thought (Human Cognitive Processing 4), 337-357. Amsterdam: John Benjamins.

Panther, Klaus-Uwe \& Linda L. Thornburg. 2002. The roles of metaphor and metonymy in English -er nominals. In René Dirven \& Ralf Pörings (eds.), Metaphor and metonymy in comparison and contrast (Cognitive Linguistics Research 20), 279-319. Berlin: Mouton de Gruyter.

Panther, Klaus-Uwe \& Linda L. Thornburg. 2007. Metonymy. In Dirk Geeraerts \& Hubert Cuyckens (eds.), The Oxford handbook of cognitive linguistics, 236-263. Oxford University Press: Oxford.

Peirsman, Yves \& Dirk Geeraerts. 2006. Metonymy as a prototypical category. Cognitive Linguistics 17. 269-316.

Radden, Günter. 2005. The ubiquity of metonymy. In José Luis Otal Campo, Ignasi Navarro i Ferrando \& Bellés Fortuño Begoña (eds.), Cognitive and discourse approaches to metaphor and metonymy (Estudis filològics 19), 11-28. Castelló de la Plana: Publicacions de la Universitat Jaume I.

Radden, Günter \& Zoltán Kövecses. 1999. Towards a theory of metonymy. In Klaus-Uwe Panther \& Günter Radden (eds.), Metonymy in language and thought (Human Cognitive Processing 4), 17-59. Amsterdam: John Benjamins. 
Šanskij, N. M. 1968. Očerki po russkomu slovoobrazovaniju. Moscow: Izdatel'stvo MGU.

Švedova, N. Ju. (ed.). 1980. Russkaja grammatika. Moscow: Nauka.

Townsend, Charles E. 1975. Russian word-formation. Columbus, OH: Slavica Publisher.

Townsend, Charles E. \& Eric S. Komar. 2000. Czech through Russian. Bloomington, IN: Slavica Publishers.

Warren, Beatrice. 1999. Aspects of refernetial metonymy. In Klaus-Uwe Panther \& Günter Radden (eds.), Metonymy in language and thought (Human Cognitive Processing 4), 121-138. Amsterdam: John Benjamins.

AUTHOR CONTACT INFORMATION

Laura A. Janda

University of Tromsø

Department of Language and Linguistics

NO-9037 Tromsø

Norway

laura.janda@uit.no 